\title{
Effect of staurosporine-induced apoptosis on endothelial nitric oxide synthase in transfected COS-7 cells and primary endothelial cells
}

\author{
M Tesauro ${ }^{1,2}$, WC Thompson ${ }^{1}$ and J Moss ${ }^{\star, 1}$ \\ ${ }^{1}$ Pulmonary-Critical Care Medicine Branch, National Heart, Lung, and Blood \\ Institute, National Institutes of Health, 9000 Rockville Pike, Building10/Room \\ 6D03, Bethesda, MD 20892-1590, USA \\ ${ }^{2}$ Current address: Laboratory of Molecular Medicine, Department of Internal \\ Medicine, University of Rome 'Tor Vergata', Rome, Italy \\ * Corresponding author: J Moss, Pulmonary-Critical Care Medicine Branch, \\ National Heart, Lung, and Blood Institute, National Institutes of Health, 9000 \\ Rockville Pike, Building10/Room 6D03, Bethesda, MD 20892-1590, USA. \\ Tel: 301-496-1597; Fax: 301-496-2363; E-mail: mossj@nhlbi.nih.gov
}

Received 06.7.05; accepted 11.7.05; published online 30.9.05

Edited by V De Laurenzi

\begin{abstract}
Nitric oxide (NO) may block apoptosis by inhibiting caspases via S-nitrosylation of cysteines. Here, we investigated whether effector caspases might cleave and thereby inhibit endothelial nitric oxide synthase (eNOS). Exposure of eNOS-transfected COS-7 cells and bovine aortic endothelial cells to staurosporine resulted in significant loss of 135-kDa eNOS protein and activity, and appearance of a $60-\mathrm{kDa}$ eNOS fragment; effects were inhibited by the general caspase inhibitor, benzyloxycarbonyl-Val-Ala-Asp[OMe]-fluoromethyl ketone (zVAD-fmk). In eNOS-transfected COS-7 cells, staurosporine-induced activation of caspase-3 and poly(ADP-ribose) polymerase (PARP) cleavage coincided with increased eNOS degradation and decreased activity. Loss of eNOS activity was greater than the degree of proteolysis. Incubation of immunoprecipitated eNOS with caspase-3, caspase-6 or caspase-7 resulted in eNOS cleavage. Staurosporine, a general protein kinase inhibitor, also reduced phosphorylation and decreased calmodulin binding, an effect that may explain the reduction in activity. eNOS, therefore, is both an inhibitor of apoptosis and a target of apoptosis-associated proteolysis.

Cell Death and Differentiation (2006) 13, 597-606.

doi:10.1038/sj.cdd.4401770; published online 30 September 2005
\end{abstract}

Keywords: eNOS; endothelial nitric oxide synthase; nitric oxide; caspases; apoptosis

Abbreviations: $\mathrm{NO}$, nitric oxide; eNOS, endothelial nitric oxide synthase; CaM, calmodulin; PARP, poly(ADP-ribose) polymerase; zVAD-fmk, benzyloxycarbonyl-Val-Ala-Asp[OMe]-fluoromethyl ketone; BAEC, bovine aortic endothelial cells; IP, immunoprecipitation

\section{Introduction}

Apoptosis, or programmed cell death, is characterized by cell shrinkage, membrane blebbing, chromatin condensation,
DNA fragmentation and selective cleavage of proteins by caspases. ${ }^{1-3}$ The central molecular initiators and executors of apoptosis are a protease family known as caspases. ${ }^{4-7}$ Caspase participation in each of the two main apoptotic pathways has been demonstrated. The first pathway involves the release of cytochrome $c$ from mitochondria. Cytochrome $c$ in the presence of ATP promotes the assembly of the apoptosome complex, which includes apoptotic proteaseactivating factor-1 and procaspase-9. Apoptosome-mediated caspase- 9 cleavage then leads to the activation of effector caspases (caspase-3, caspase-6 and caspase-7), resulting in cell death. ${ }^{1,4,8}$ The second apoptotic pathway involves signaling by cell surface death receptors such as TNFR-1 or Fas, which, through adaptor molecules, promote caspase-8 cleavage, leading to apoptosis. ${ }^{1,8}$ In both pathways, activated caspase-3, one of the final products of the protease cascade, can cleave a number of key cellular proteins including poly(ADP-ribose) polymerase, an enzyme important for DNA repair. PARP is cleaved to a $89-\mathrm{kDa}$ fragment, which is often used as an indicator of apoptosis. ${ }^{9}$ The mitochondrial pathway appears to mediate apoptosis resulting from exposure to staurosporine without involvement of the Fas/ Fas-ligand/ caspase-8 pathway. ${ }^{9,10}$

Caspases, a family of least 14 mammalian aspartatespecific, cysteine-protease isoenzymes that are present in cells, constitutively as inactive zymogens, are grouped into two categories by structure and function., ${ }^{5,1}$ Activation of 'initiator caspases' such as caspase- 8 and -9 begins a 'caspase cascade' in which downstream 'effector caspases' such as caspase-3, -6 , and -7 are cleaved by upstream initiator caspases to form active heterodimers, which then proteolyze specific protein substrates. ${ }^{5-7}$

Nitric oxide (NO), a lipophilic, free-radical gas with a half-life of seconds, is synthesized by a family of enzymes called nitric oxide synthases (NOS). Three NOS isoforms have been identified: one inducible (iNOS, type II), and two constitutive, the neuronal (nNOS, type I) and endothelial (eNOS, type III) enzymes. ${ }^{12-15}$ eNOS plays a major role as a vasoprotective molecule, maintaining vascular tone and integrity. Similar to other NOS isoforms, eNOS contains N-terminal oxygenase and $\mathrm{C}$-terminal reductase domains with an intervening calmodulin (CaM)-binding domain. eNOS enzymatic activity is tightly regulated at multiple levels by calcium, CaM and phosphorylation (e.g. serine-1177, in the reductase domain, and threonine-495, in the CaM-binding domain), as well as by protein-protein interactions. ${ }^{16,17}$

$\mathrm{NO}$ can have either pro- or antiapoptotic effects in different types of cells, dependent on its concentration and the overall oxidative status of the cell, among other factors. ${ }^{18-20}$ Antiapoptotic effects of NO have been attributed to its ability to inhibit the caspase cascade via reversible S-nitrosylation of key cysteine residues in various caspases. ${ }^{20-24}$ Thus, eNOS-synthesized NO inhibited caspase-mediated apoptosis 
in endothelial cells; ${ }^{23}$ it has been speculated that diminished production or availability of $\mathrm{NO}$ and enhanced apoptosis is related to susceptibility to atherosclerosis or age-related endothelial dysfunction. ${ }^{25-28}$

In view of a role for eNOS in endothelial cell apoptosis, the effect of staurosporine-induced apoptosis on levels of eNOS protein and activity was studied in COS-7 cells, overexpressing eNOS, and in bovine aortic endothelial cells (BAEC). We hoped to determine whether eNOS, having a role as an inhibitor of apoptosis, may itself be a target of apoptosismediated events.

\section{Results}

\section{Effect of caspase inhibition on staurosporine- induced reduction of eNOS protein and activity}

Initial studies indicated that 24-h incubation of COS-7 cells overexpressing human aortic eNOS with staurosporine reduced eNOS protein and activity to levels less than $50 \%$ of those in control transfected cells (Figure 1). To confirm that decreases in eNOS protein and activity were related to caspase-mediated events, the eNOS-transfected COS-7 cells were treated with staurosporine in the presence of the nonspecific caspase inhibitor, benzyloxycarbonyl-Val-AlaAsp[OMe]-fluoromethyl ketone (zVAD-fmk), which prevented the effect of staurosporine, and in its absence, increased eNOS protein and activity ca. $100 \%$. The effects of staurosporine on eNOS activity and proteolytic degradation were concentration-dependent (Figure 2). After $8 \mathrm{~h}$ in the presence of between 6 and $20 \mathrm{nM}$ staurosporine, concentration-dependent decrease in eNOS activity (Figure 2, lower panel) and increase in eNOS proteolysis, as indicated by increasing accumulation of an immunoreactive eNOS 60-kDa fragment (Figure 2, upper panel), were observed. Comparison of the densiometric ratio for full-length $135-\mathrm{kDa}$ eNOS in treated versus untreated cells revealed no statistically significant change ( $t$-test, $P<0.05, n=3$ per time point). In contrast, comparision of the densiometric ratio of $60-\mathrm{kDa}$ eNOS in treated versus untreated cells between $6 \mathrm{nM}$ and $2.0 \mu \mathrm{M}$ staurosporine showed a dose-dependent linear increase (correlation coefficient $=0.942$ ), reaching a statistically significant ( $t$-test, $P<0.05, n=3$ per time point) $\sim 5$-fold increase over that of untreated cells at $2.0 \mu \mathrm{M}$ staurosporine (Figure 2). The percentage decrease in eNOS activity after $8 \mathrm{~h}$ in the presence of staurosporine, however, was much greater than the densiometrically observed (Figures 2 and $5 \mathrm{a}$ ) degradation of total immunoreactive eNOS protein.

To confirm that caspase-mediated effects on endogenous eNOS protein and activity could also be detected in nontransfected cells, primary BAEC were exposed to staurosporine with or without ZVAD-fmk (Figure 3). Exposure of BAEC to $500 \mathrm{nM}$ staurosporine for $18 \mathrm{~h}$ resulted in a ca. $80 \%$ decrease in eNOS protein and activity (Figure 3). In BAEC treated with staurosporine in combination with the general caspase inhibitor, ZVAD-fmk, eNOS protein and activity were approximately twice those in staurosporine-treated cells, but still well below those in untreated control cells (Figure 3). In BAEC, the caspase inhibitor alone failed

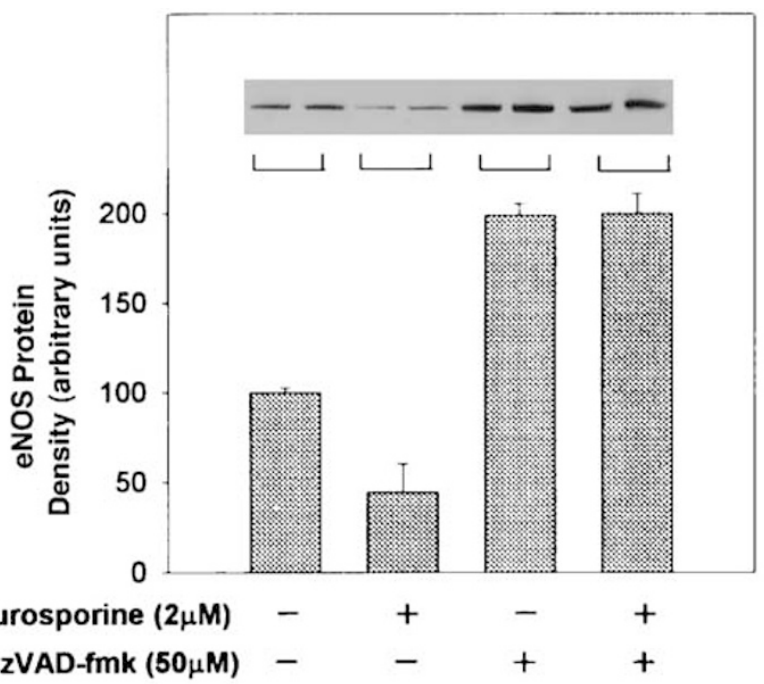

b

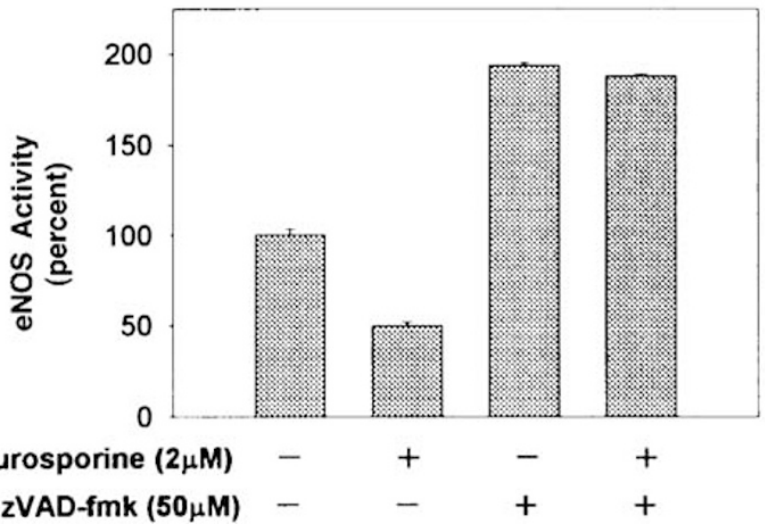

Figure 1 Effect of the general caspase inhibitor, zVAD-fmk, on staurosporineinduced reduction in eNOS protein and activity in eNOS-transfected COS-7 cells. Confluent COS-7 cells were transiently transfected with eNOS CDNA as described in Materials and Methods. Cells were incubated as indicated without or with $2 \mu \mathrm{M}$ staurosporine added $24 \mathrm{~h}$ before harvest, and/or $50 \mu \mathrm{M}$ zVAD-fmk or $0.1 \%$ DMSO vehicle (final concentration) added $48 \mathrm{~h}$ before harvest. (a) Cells from duplicate dishes were collected $72 \mathrm{~h}$ after transfection and immunoprecipitated eNOS was quantified by densitometry after immunoblotting. Data are presented as means of values from duplicate samples (shown in blot) + one-half the range. (b) In a separate experiment, duplicate samples of cells were treated with staurosporine, zVAD-fmk and/or vehicle exactly as in (a). eNOS activity (mean \pm one-half the range) in samples of lysates $(30 \mu \mathrm{g})$ is reported relative to that of cells incubated without additions $(781 \pm 29 \mathrm{fmol}$ citrulline $/ \mathrm{min} / \mathrm{mg}$ protein $=100 \%)$. Results were similar in two other experiments

to increase eNOS activity and protein above basal levels as it did in the COS-7 cells overexpressing eNOS (Figure 1) and, in fact, decreased both eNOS activity and protein by about $20 \%$. In both transfected and primary cells, staurosporine treatment in combination with the general caspase inhibitor, zVAD-fmk, led to significantly (over two-fold) greater eNOS activity and protein levels than were found in cells treated with staurosporine alone. As shown in Figures 1 and 3, total eNOS protein and activity changed in parallel after long-term (18-24h) treatment of cells with staurosporine and/or caspase inhibitors. These data differ from those shown in Figure 2, where cells were incubated for $8 \mathrm{~h}$ with the agents and effects on activity did not parallel those on eNOS protein. 


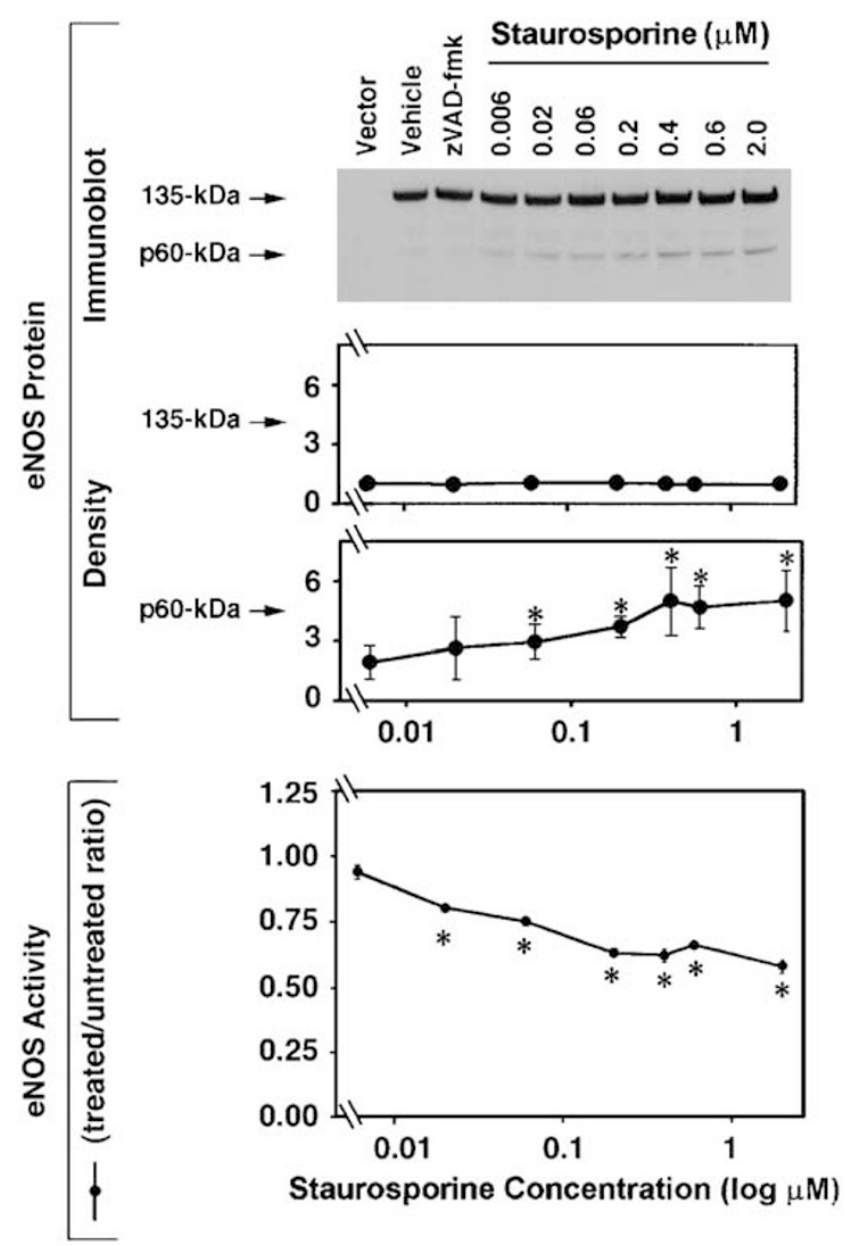

Figure 2 Concentration-dependent effect of staurosporine on the formation of the p60-kDa fragment and eNOS activity. (Top) At $24 \mathrm{~h}$ after transfection with vector or eNOS cDNA, COS-7 cells were incubated with $5 \mu \mathrm{M}$ zVAD-fmk for $24 \mathrm{~h}$ followed by replacement of medium with vehicle (DMSO), $50 \mu \mathrm{M}$ zVAD-fmk or staurosporine at the indicated concentration and incubated for an additional $8 \mathrm{~h}$ before IP of proteins from duplicate 100-mm dishes with anti-eNOS antibodies, separation of proteins by LDS-PAGE and immunoblotting for eNOS. Densitometry is presented as means of values from three experiments \pm S.E. reported relative to that of untreated cells $=1$, with significant increase from untreated cells indicated ( ${ }^{*} P<0.05$, $t$-test). (Bottom) In a separate experiment, duplicate dishes of cells were treated with staurosporine, zVAD-fmk and/or vehicle exactly as in (top) before assay of eNOS activity in sample $(20 \mu \mathrm{g})$ lysates in triplicate. Data are eNOS activity (mean \pm S.E.) and statistical significance (t-test, ${ }^{*} P<0.05$ ) expressed relative to the activity of lysates from vehicle-treated eNOS-transfected control cells $=1.00$, which represents $400 \pm 0.8 \mathrm{fmol}$ citrulline/ $\mathrm{min} / \mathrm{mg}$ (data not shown). Results are representative of three independent experiments

\section{Effects of staurosporine on phosphorylation of eNOS serine-1177 and threonine-495}

Phosphorylation of eNOS is one means of regulating its activity. ${ }^{16}$ Since 8 -h incubation of eNOS-transfected cells with different concentrations of the general protein kinase inhibitor, staurosporine, resulted in decreased eNOS activity that did not appear to parallel the loss of total immunoreactive eNOS (Figure 2), the effects of this agent on eNOS phosphorylation at serine-1177 and threonine-495 were investigated (Figure 4). As shown in Figure 4, staurosporine decreased phosphorylation of both serine-1177 and threonine-495 in a
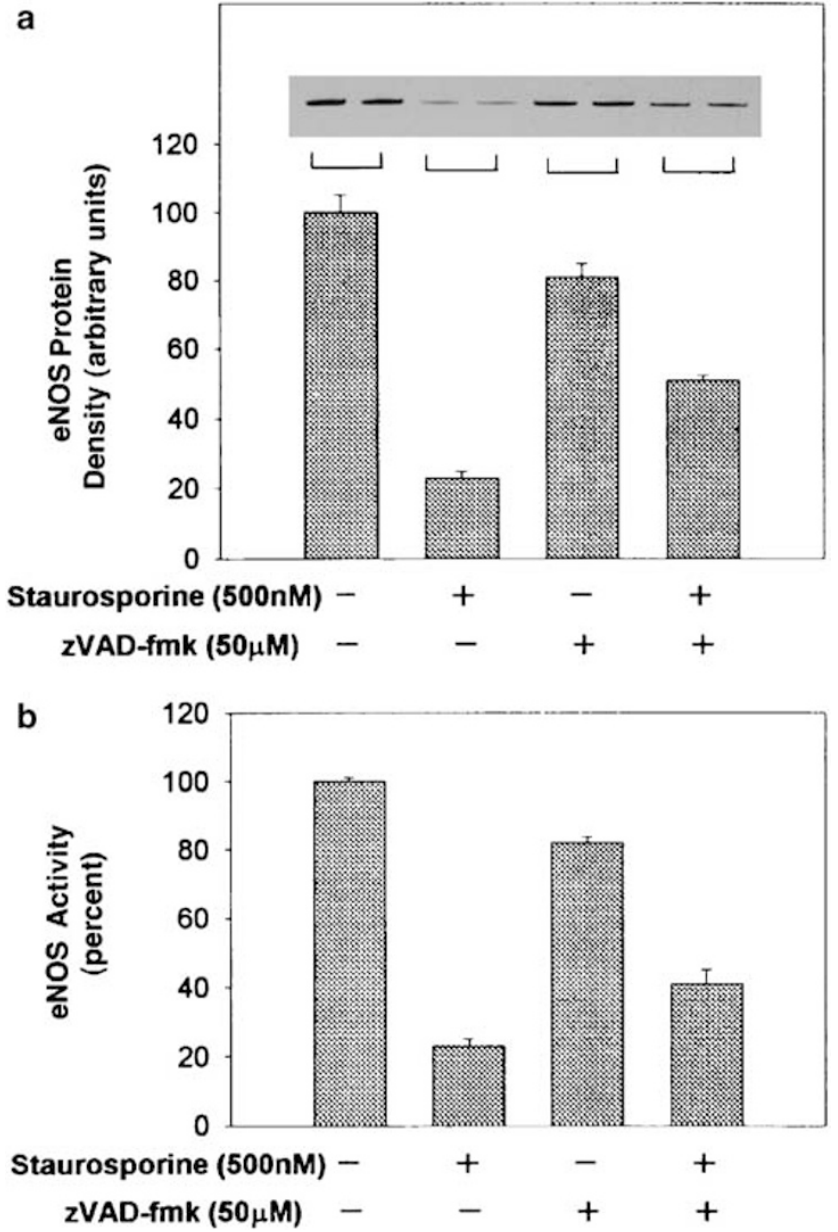

Figure 3 Effect of the general caspase inhibitor, zVAD-fmk, on staurosporineinduced reduction of endogenous eNOS protein and activity in BAEC. Proteins precipitated with anti-eNOS antibody from triplicate $100-\mathrm{mm}$ dishes of confluent BAECs that had been incubated for $18 \mathrm{~h}$ without or with $500 \mathrm{nM}$ staurosporine and/or $50 \mu \mathrm{M}$ zVAD-fmk or $0.1 \%$ DMSO, as indicated, were used to assay eNOS activity and protein, as described in Materials and Methods. (a) eNOS protein, expressed relative to that of cells incubated with DMSO only $=100$, was quantified by densitometry after immunoblotting and is presented as in Figure 1a. (b) Immunoprecipitated proteins from the same lysates shown in (a) were assayed for eNOS activity. $100 \%=$ eNOS activity immunoprecipitated from three confluent, untreated dishes, which is $11.0 \pm 0.1 \mathrm{fmol} / \mathrm{min}$. Results were similar in two other experiments

concentration-dependent manner. Significant effects on eNOS phosphorylation at both sites were detected with $60 \mathrm{nM}$ staurosporine, whereas significant decreases in eNOS activity and proteolysis were detected at lower staurosporine concentrations (6-20 nM) (Figure 2). These data suggest that effects on phosphorylation at these sites do not explain effects on eNOS activity.

\section{Effect of staurosporine on eNOS, PARP and caspase-3}

We next sought to determine if reduction in eNOS activity and increase in eNOS degradation followed induction of caspase3 activity and related PARP cleavage, two markers of 

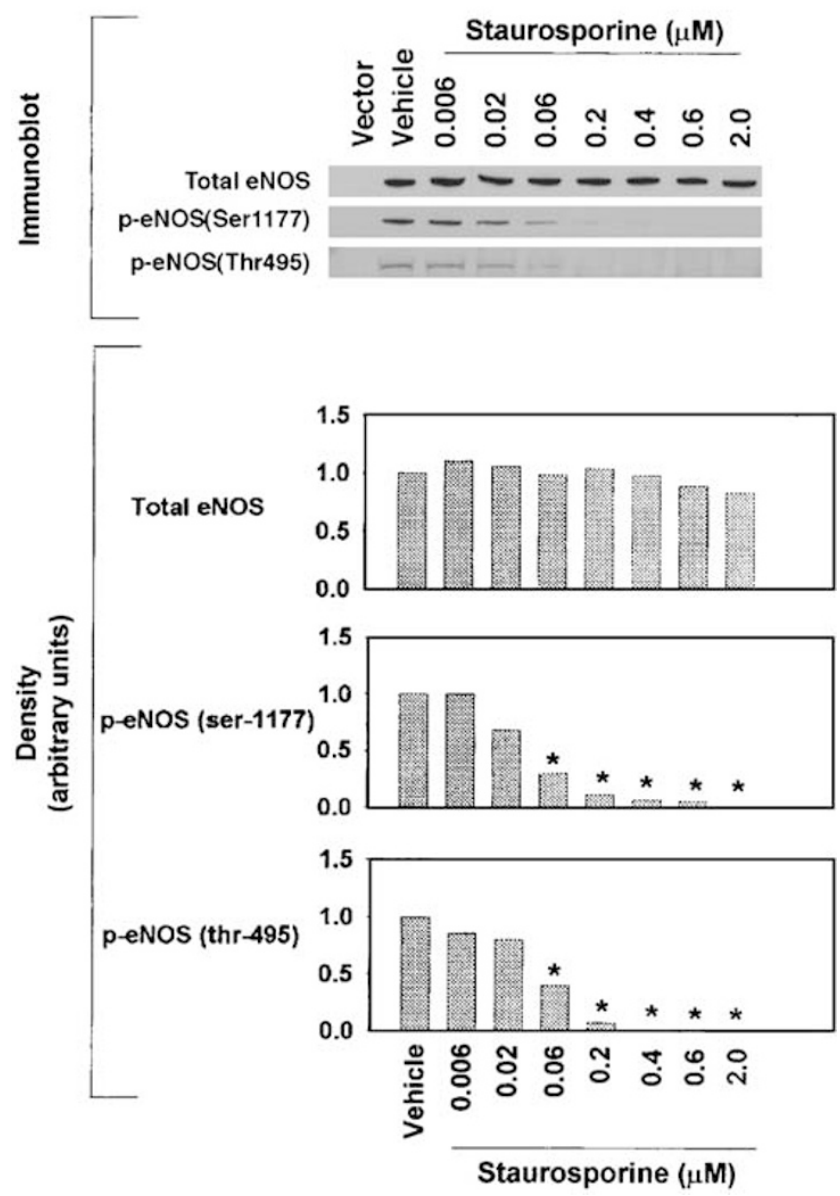

Figure 4 Effect of staurosporine concentration on phosphorylation of eNOS at serine-1177 or threonine-495. Confluent COS-7 cells, $24 \mathrm{~h}$ after transfection with vector or eNOS cDNA, were incubated with $5 \mu \mathrm{M}$ zVAD-fmk for $24 \mathrm{~h}$. The medium was replaced and cells were incubated for an additional $8 \mathrm{~h}$ with vehicle (DMSO) or staurosporine (various concentrations), as indicated. Proteins precipitated with anti-eNOS antibody from duplicate $100-\mathrm{mm}$ dishes were separated by LDS-PAGE and quantified by densitometry after immunoblotting with the indicated antibodies against eNOS proteins or specific phosphorylated sites. Results shown are representative of three independent experiments with significant reductions $\left({ }^{\star} P<0.05\right)$ in $p$-eNOS $(S 1177)$ and $p$-eNOS(T495)

apoptosis. We measured eNOS activity and protein, as well as caspase-3 activity and PARP cleavage, during incubation of eNOS-transfected COS-7 cells with staurosporine over $8 \mathrm{~h}$ (Figure 5). Caspase-3 activity was increased after $2 \mathrm{~h}$ and was maximal (ca. 3.5-4 times initial basal level) between 4 and $8 \mathrm{~h}$ with staurosporine (Figure $5 \mathrm{~b}$ ). Accumulation of the $89-\mathrm{kDa}$ PARP fragment increased in parallel with caspase-3 activity, but perhaps more slowly (Figure $5 \mathrm{~b}$ ). A significant loss of eNOS activity ( $\sim 30 \%, 8 \mathrm{~h}$ after staurosporine treatment) and an increase of p60-kDa C-terminal eNOS cleavage fragment (Figures $5 \mathrm{a}$ and $6 \mathrm{a}$ ) were seen from 2 to $8 \mathrm{~h}$, following the increase in caspase- 3 activity and appearance of PARP cleavage fragment (Figure $5 \mathrm{~b}$ ). The amount of $60-\mathrm{kDa}$ cleavage fragment increased with duration of staurosporine exposure, along with induction of the two apoptotic markers. As noted in Figure $5 c$, staurosporine-induced increases in PARP cleavage were concentration-dependent beginning at $6 \mathrm{nM}$ staurosporine, a concentration where the staurosporine- induced, concentration-dependent eNOS cleavage was starting to be observed (Figure 2, upper panel). Thus, the reduction in eNOS activity and increase in eNOS degradation, following induction of PARP cleavage and increasing caspase-3 activity, would be consistent with cleavage of eNOS by caspase-3 upon induction of apoptosis. During initial caspase activation $(2-8 \mathrm{~h})$, the loss of eNOS activity was clearly greater than the densitometrically observed decreases in 135kDa eNOS (Figures 2 and 5a).

\section{Effect of caspase inhibitors on staurosporine- induced eNOS cleavage}

Since staurosporine-induced eNOS cleavage in transfected COS-7 cells was inhibited by the general caspase inhibitor, zVADfmk (Figure 6a), we used several other caspase inhibitors to assess further a caspase-catalyzed degradative process (Figure 6b). COS-7 cells overexpressing eNOS were incubated for $2 \mathrm{~h}$ with $50 \mu \mathrm{M}$ of different inhibitors, followed by $6 \mathrm{~h}$ with staurosporine plus the inhibitor. Staurosporineinduced eNOS fragmentation was inhibited best by zVAD-fmk (general caspase inhibitor) and zVEID-fmk (caspase-6 inhibitor), and less so by zDEVD-fmk (caspase-3, caspase-7 and caspase-10 inhibitor). zWEHD-fmk (caspase-1, caspase4 and caspase-5 inhibitor) and zLETD-fmk (caspase-8 inhibitor) were statistically ( $t$-test, $P<0.05, n=2$ ) least effective. Thus, from the proposed specificity of caspase inhibitors, at these concentrations it appeared that certain inhibitors of executioner caspases, in particular, inhibitors of caspase-3, caspase- 6 and caspase-7, as well as the general caspase inhibitor zVAD-fmk, prevented staurosporine-induced eNOS cleavage in COS-7 cells overexpressing eNOS.

\section{eNOS proteolysis by caspase-3, caspase- 6 or caspase-7}

To determine whether caspase- 3 or caspase- 6 could act directly on eNOS as a substrate, we incubated immunoprecipitated eNOS without or with the active recombinant caspase (Figure 7a). After incubation $\left(1 \mathrm{~h}, 30^{\circ} \mathrm{C}\right)$ of eNOS immunoprecipitated from vector-transfected control (lane 1) or eNOS-transfected cells without (lanes 2,3 ) or with caspase3 (lane 5) or caspase-6 (lane 7) in the presence of inhibitor (zVAD-fmk), there was little, if any, cleavage of eNOS to the p60-kDa form (Figure 7a). In contrast, p60-kDa eNOS was present after incubation with either caspase-3 (lane 4) or caspase-6 (lane 6). To determine the concentration-dependence of this effect, equal amounts of immunoprecipitated eNOS were incubated $\left(1 \mathrm{~h}, 30^{\circ} \mathrm{C}\right)$ in the presence of varying concentrations of either caspase-3 or caspase- 6 (Figure $7 \mathrm{~b}$ ) and accumulation of the p60-kDa fragment was monitored by immunoblotting for eNOS followed by densitometry. Both caspase- 3 and caspase- 6 caused concentration-dependent increases in p60-kDa formation from immunoprecipitated eNOS. To determine if caspase-7 could act on eNOS as a substrate, we incubated equal amounts of immunoprecipitated eNOS without or with active recombinant caspase-3 or caspase-7 (each $20 \mathrm{U} / \mu \mathrm{l}$, final concentration, $1 \mathrm{~h}, 30^{\circ} \mathrm{C}$, Figure 7c). The amount of $60-\mathrm{kDa}$ eNOS formed by incubation 

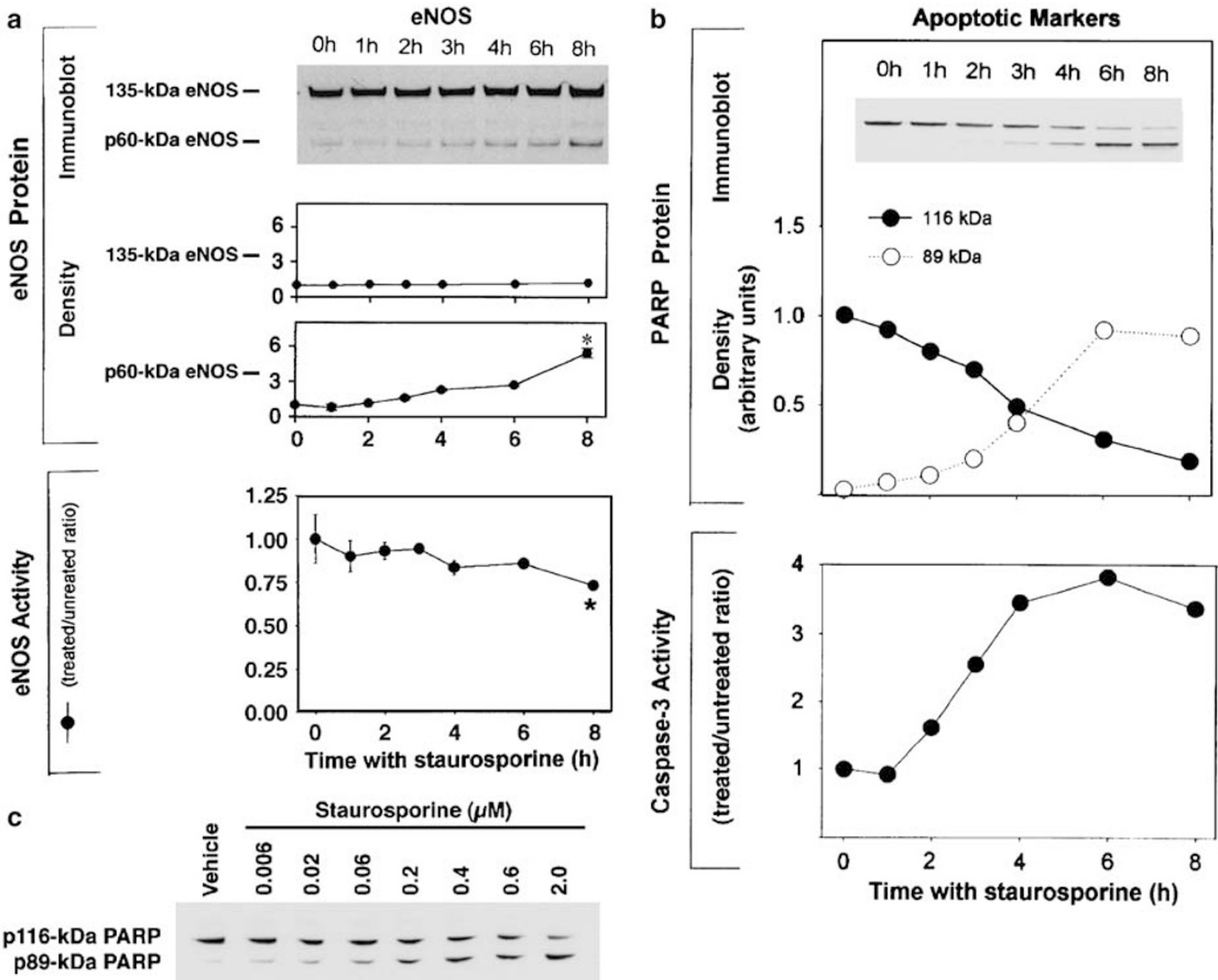

Figure 5 Effect of staurosporine on eNOS protein and activity, PARP and caspase-3 activity. Confluent COS-7 cells, $48 \mathrm{~h}$ after transfection with eNOS cDNA, were incubated without or with $2 \mu \mathrm{M}$ staurosporine for the indicated times $(\mathbf{a}$ and $\mathbf{b})$ or for $8 \mathrm{~h}$ with the indicated concentration of staurosporine or vehicle (c). (a) Proteins were precipitated from duplicate 100-mm dishes with anti-eNOS antibody for quantification of eNOS protein and activity, which are reported relative to that of cells from two dishes of untreated transfected cells $=1,{ }^{*} P<0.05$ compared to untreated cells. (b and $\mathbf{c}$ ) Samples of lysates from cells incubated as described were subjected to LDSPAGE and immunoblotting followed by densitometry to quantify PARP protein levels, which is reported relative to the density of the $116-\mathrm{kDa}$ band at zero time $=1.0$, or were assayed for caspase-3 activity, which is reported relative to that of untreated cells at zero time $=1.0$. Results shown were replicated in two independent experiments

with caspase- 7 was consistently less $(26 \pm 1.4 \%$, three independent experiments) than that formed by incubation with caspase-3. These data support the conclusion that eNOS serves as a substrate for the effector caspases, caspase-3, caspase- 6 and caspase-7, consistent with the findings in intact cells.

\section{Effect of staurosporine on association of CaM with eNOS}

Based on the size of the $60-\mathrm{kDa}$ eNOS fragment, it was predicted that incubation of cells with staurosporine might modify the eNOS protein in the vicinity of the CaM-binding site and perhaps alter CaM binding. As shown in Figure 8a, two independent methods were used to evaluate staurosporineinduced alterations in the interactions of CaM with eNOS: (1) the ability of antibodies specific for eNOS to co-immunoprecipitate CaM, or (2) the ability of eNOS to bind to immobilized CaM. Staurosporine caused a biphasic effect on CaM association with eNOS. No significant change in CaM binding was observed from 2 to $4 \mathrm{~h}$; incubation for longer times, up to $8 \mathrm{~h}$, caused a significant decrease $(45 \pm 10 \%, P<0.05, t$-test, four independent co-immunoprecipitation (IP) experiments) in CaM bound to immunoprecipitated eNOS at the $8 \mathrm{~h}$ time point. To demonstrate that loss of CaM binding at the 6-8 h time point was associated with formation of the staurosporineinduced 60-kDa eNOS fragment, we co-immunoprecipitated eNOS and CaM from lysates of vehicle-treated cells or from cells treated for 6 or $8 \mathrm{~h}$ with staurosporine (Figure $8 \mathrm{~b}$ ). Only co-IPs in which the $60-\mathrm{kDa}$ eNOS fragment was detected showed reduced $\mathrm{CaM}$ binding $(P<0.05$, $t$-test, with reductions of 33 and $45 \%$ at 6 and $8 \mathrm{~h}$, respectively).

\section{Discussion}

NO can have an important role in apoptosis. ${ }^{18,19}$ There is increasing evidence that alterations in NO production affect signal transduction pathways that control apoptotic cell 


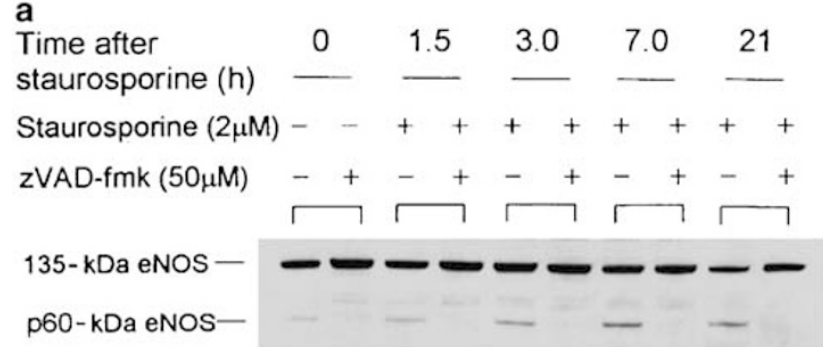

b Staurosporine $(2 \mu \mathrm{M})-++++++-$

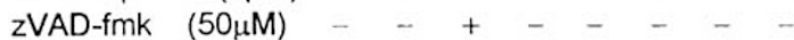
zWEHD-fmk $(50 \mu \mathrm{M})$ - $\quad-\quad-\quad+\quad-\quad-$ zDEVD-fmk $(50 \mu \mathrm{M})-{ }_{-}-{ }_{-}+-$ zVEID-fmk $(50 \mu \mathrm{M})$ - $\quad-\quad-\quad-\quad+-$ zLETD-fmk $(50 \mu \mathrm{M})$ - $\quad-\quad-\quad-\quad+$

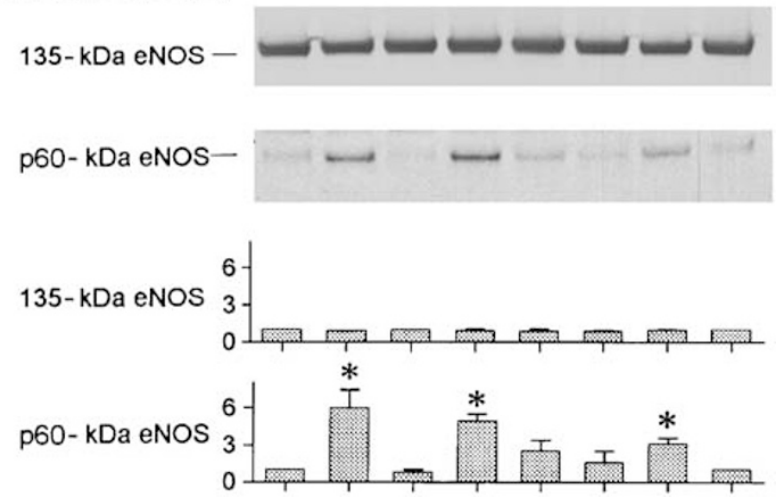

Figure 6 Effect of caspase inhibitors on staurosporine-induced eNOS cleavage. (a) Incubation without or with $50 \mu \mathrm{M}$ zVAD-fmk was initiated $24 \mathrm{~h}$ after transfection of confluent COS-7 cells with eNOS CDNA, and $24 \mathrm{~h}$ later, incubation without or with $2 \mu \mathrm{M}$ staurosporine at the indicated time was initiated and thereafter, cells were harvested for precipitation of proteins with anti-eNOS antibodies and immunoblotting for eNOS. (b) At $48 \mathrm{~h}$ after transfection, the indicated inhibitor $(50 \mu \mathrm{M})$ was added to cells and $2 \mathrm{~h}$ later $2 \mu \mathrm{M}$ staurosporine was added as indicated, followed by incubation for $6 \mathrm{~h}$ before precipitation of proteins with anti-eNOS antibodies, and immunoblotting for eNOS protein. Densitometry is reported relative to that of untreated cells at time zero $=1 \pm$ onehalf the range with significant changes from untreated cells indicated $\left({ }^{*} P<0.05\right.$, t-test). Results shown are representative of those in two independent experiments

death. ${ }^{19,23,26}$ Our results show that staurosporine-induced reduction in eNOS activity was associated with caspasemediated cleavage of eNOS. Long-term (18-24 h) exposure of either eNOS-transfected COS-7 cells or BAECs to staurosporine resulted in a significant loss of eNOS protein and activity, an effect that was significantly reduced by caspase inhibitors. Sensitivity of BAEC to staurosporine was significantly greater than that of COS-7 cells overexpressing human eNOS. In addition, relative amounts of eNOS protein and activity were much lower in BAEC treated with staurosporine plus caspase inhibitor than they were in COS-7 cells overexpressing eNOS. These data are consistent with the hypothesis that, prior to staurosporine exposure, eNOS-transfected COS-7 cells have a high basal rate of apoptosis and caspase activation not present in BAEC which, when inhibited by the general caspase inhibitor, zVADfmk, leads to increased eNOS protein and activity

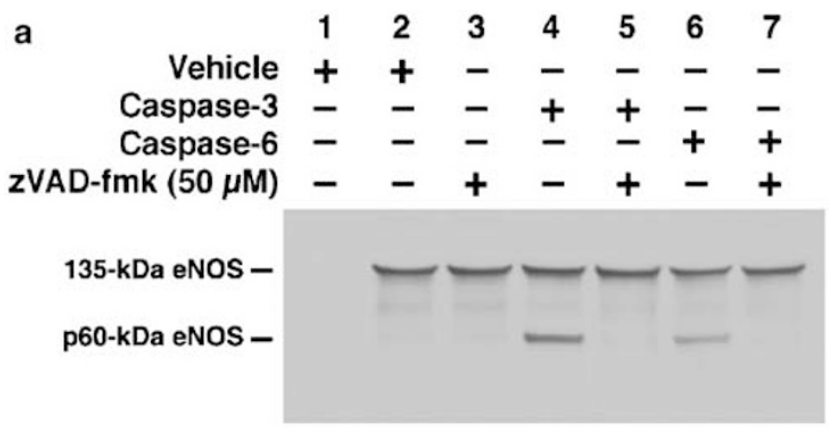

b
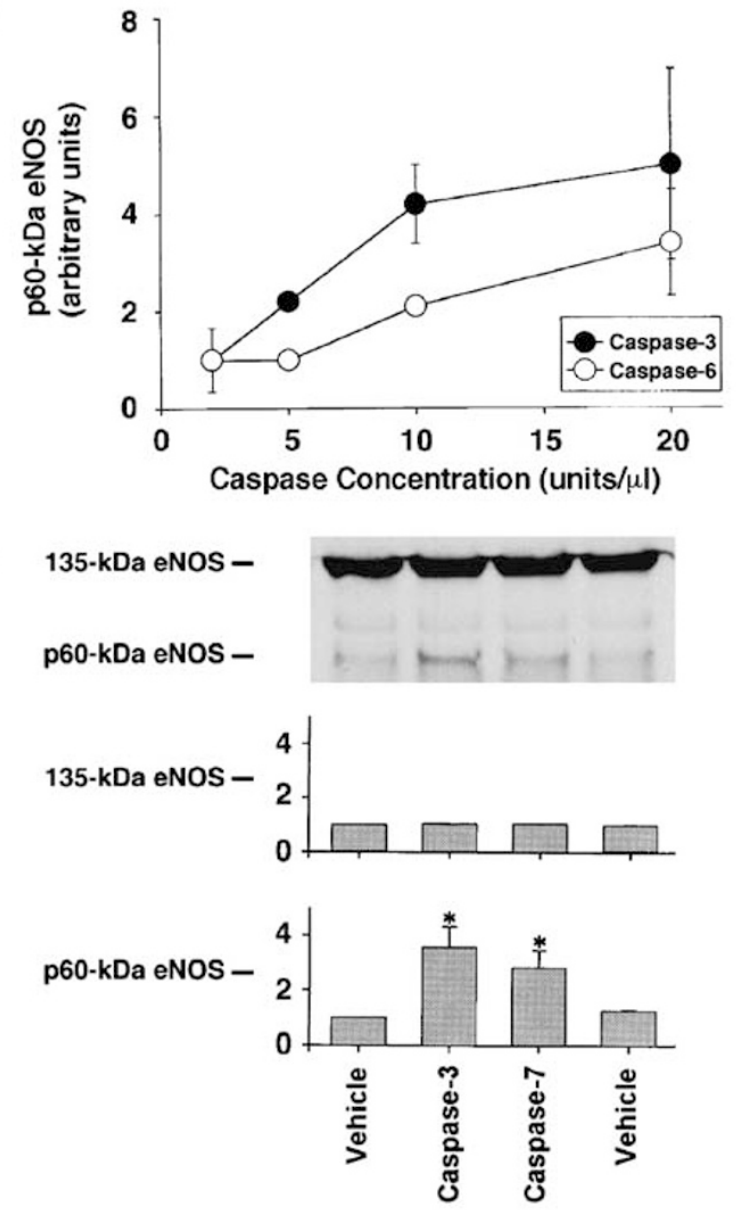

Figure 7 Cleavage of eNOS by caspase-3, caspase- 6 and caspase- 7 in vitro. Confluent COS-7 cells $24 \mathrm{~h}$ after transfection with vector or eNOS CDNA were incubated with $5 \mu \mathrm{M}$ zVAD-fmk for $24 \mathrm{~h}$ before IP of eNOS. (a) Samples of immunoprecipitated proteins were incubated $\left(30^{\circ} \mathrm{C}, 1 \mathrm{~h}\right)$ without or with recombinant caspase-3 or caspase- $6(20 \mathrm{U} / \mu \mathrm{l}$, final concentration) without or with $50 \mu \mathrm{M}$ zVAD-fmk or vehicle ( $40 \mu$ l total volume) before the addition of $20 \mu \mathrm{l}$ LDS sample buffer, separation of proteins by LDS-PAGE and immunoblotting for eNOS. (b) Replicate samples of immunoprecipitated proteins were incubated as in (a) with the indicated concentration of recombinant caspase-3 or caspase-6 before separation of proteins by LDS-PAGE and densitometry to quantify the p60-kDa eNOS fragment. Data are presented as means of values from duplicate samples \pm one-half the densiometric range. (c) Samples of immunoprecipitated proteins were incubated exactly as in (a) without or with recombinant caspase-3 or caspase-7 before the addition of $20 \mu$ LDS sample buffer, separation of proteins by LDS-PAGE and immunoblotting for eNOS. Densitometry from three experiments is reported relative to that of immunoprecipitated eNOS incubated without caspase $=1 \pm$ S.E. with significant changes from untreated cells indicated $\left({ }^{*} P<0.05, t\right.$-test, $\left.n=3\right)$ 
levels. Additionally, the primary BAEC appear more sensitive to staurosporine-induced apoptotic stimuli than the immortalized COS-7 cell line.

Short-term (2-8 h) initial staurosporine-induced reduction in eNOS activity and appearance of an immunoreactive $60-\mathrm{kDa}$ eNOS degradation product followed induction of two markers of apoptosis, PARP cleavage and caspase-3 activity (Figure 5). Cleavage of PARP and eNOS appeared following

a
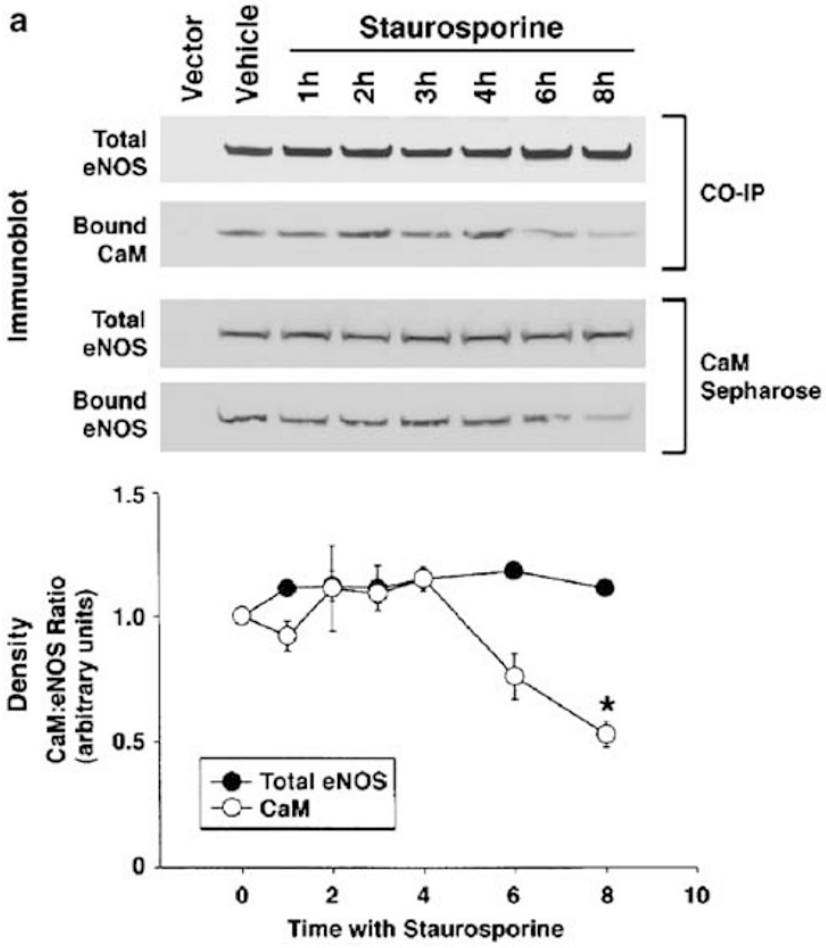

b
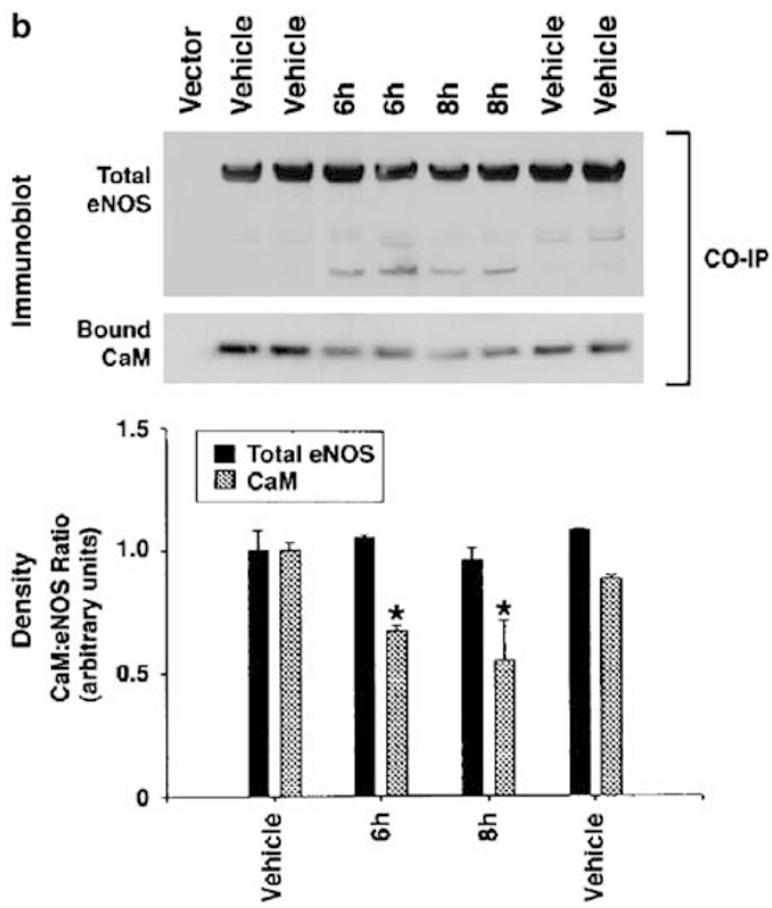

activation of caspase-3, consistent with prior studies showing that these two events are coordinated consequences of apoptosis. Additionally, staurosporine-induced increases in PARP and eNOS cleavage displayed similar dose-dependence, both detected with a concentration of staurosporine as low as $6 \mathrm{nM}$ (Figure 5c compared to Figure 2, upper panel). Consistent with caspase-dependent proteolysis as a mechanism for eNOS degradation, incubation of immunoprecipitated eNOS from transfected COS-7 cells with effector caspases (caspase-3, caspase-6 and caspase-7) resulted in specific eNOS cleavage, which for caspase- 3 and caspase- 6 was shown to be concentration-dependent (Figure 7).

The reduction in total eNOS activity seen after $8 \mathrm{~h}$ of exposure to staurosporine were disproportionate to the reduction in the amount of full-length eNOS and coincided with appearance of the 60-kDa C-terminal fragment (Figures $2,5 \mathrm{a}$ and $6 \mathrm{a}$ ). Addition of staurosporine, a general protein kinase inhibitor, resulting in differential reduction in phosphorylation of eNOS by staurosporine at one of the two main eNOS phosphorylation sites thought to regulate eNOS activity, ${ }^{16}$ either serine-1177 or threonine-495, could be one explanation for this observation. While eNOS phosphorylation at serine1177 has been shown to increase NO production (by increasing electron flux through the reductase domain), eNOS phosphorylation at threonine-495 is believed to decrease enzymatic activity (by interfering with the binding of CaM). ${ }^{16}$ However, staurosporine-induced decrease in phosphorylation of eNOS at either serine-1177 or threonine-495 occurred at similar concentrations (Figure 4). Additionally, eNOS activity declined at concentrations of staurosporine that did not affect eNOS phosphorylation (Figure 2). Thus, effects on phosphorylation and proteolysis do not explain the loss of activity. In contrast, incubation of cells with staurosporine resulted in a partial loss of CaM binding by eNOS, which paralleled accumulation of the $60-\mathrm{kDa}$ eNOS fragment, and may be responsible for decreased eNOS activity after longer incubation.

The $60-\mathrm{kDa}$ C-terminal eNOS cleavage fragment, or peptides derived in its generation, may have an inhibitory effect on eNOS activity. It is well known that dimerization of eNOS is required for activity. Lee et al. ${ }^{29}$ demonstrated that eNOS $\mathrm{N}$ - and $\mathrm{C}$-terminal truncation mutants coexpressed in

Figure 8 Effect of staurosporine on CaM binding to eNOS. Confluent COS-7 cells $24 \mathrm{~h}$ after transfection with vector or eNOS cDNA were incubated with $5 \mu \mathrm{M}$ zVAD-fmk for $24 \mathrm{~h}$ before the medium was replaced and cells were incubated for indicated times without or with vehicle (DMSO) or $2 \mu \mathrm{M}$ staurosporine. (a) Two methods were used to quantify the effect of staurosporine on CaM binding to eNOS, that is, (1) CaM Co-immunoprecipitation with eNOS (upper two panels from the same immunoblot) and (2) eNOS binding to CaM Sepharose (lower two panels from separate immunoblots). Data are presented as the densiometric means of values of total $135-\mathrm{kDa}$ eNOS (dark circles, two panels) or eNOS bound to $\mathrm{CaM}$ (open circles, two panels) at corresponding time points from both methods (shown in corresponding blots) \pm one-half the range. Four independent co-IP experiments $(n=4)$ confirmed a significant reduction $(45 \pm 10 \%$, $t$-test, $\left.{ }^{*} P<0.05\right)$ in CaM bound to immunoprecipitated eNOS at the 8-h time point. (b) Decreased CaM binding was associated with the accumulation of a $60-\mathrm{kDa}$ eNOS fragment. The amount of CaM co-immunoprecipitated with eNOS from cell incubated with $2 \mu \mathrm{M}$ staurosporine for 6 or $8 \mathrm{~h}$ (33 and $45 \%$ decrease, respectively) was significantly less $\left({ }^{*} P<0.05\right.$, $t$-test) than from cells incubated with vehicle alone. Data are presented as means of values from duplicate samples (shown in blot) \pm one-half the range 
COS-7 with full-length eNOS exerted a negative effect on eNOS activity by affecting eNOS oligomerization. Our experiments demonstrate caspase-mediated cleavage of eNOS, with the generation of a C-terminal eNOS fragment of approximately $60-\mathrm{kDa}$, implicating the closest putative caspase cleavage site at aspartate-668. COS-7 cells overexpressing the eNOS mutant (eNOS D668A) showed reduction, compared to wild-type eNOS, of $60-\mathrm{kDa}$ eNOS formation by $60 \%$ (data not shown), indicating that this and other proteolytic sites may be involved. The p60 fragment generated during apoptosis may be an in vivo effector of eNOS.

Consistent with these findings in intact cells, incubation of immunoprecipitated eNOS with caspase-3 or caspase- 6 in vitro resulted in a concentration-dependent increase in p60kDa formation (Figure $7 \mathrm{~b}$ ), consistent with eNOS serving as a direct target of apoptosis-associated proteolysis in vivo.

The cleavage of eNOS early in apoptosis may be of physiological relevance in promoting cell death. NO has been shown to inhibit endothelial cell apoptosis ${ }^{23}$ and many groups have shown inhibitory effects of NO on caspase activity. ${ }^{20-25}$ Diminished eNOS-catalyzed production of NO or its bioavailability leads to endothelial apoptosis, and it has been speculated that this is associated with enhanced susceptibility to endothelial dysfunction and atherosclerosis. ${ }^{26-28}$ As NO inhibits apoptosis in endothelial cells, it is intriguing to speculate that caspase-mediated loss of eNOS-derived NO further activates the caspase cascade, thereby promoting the apoptotic process by removing an impediment to cell death.

\section{Materials and Methods}

\section{Plasmid constructs}

Human aorta eNOS cDNA (a kind gift of T Quertermous, Harvard Medical School, Massachusetts General Hospital, Boston, USA) was ligated into the PBK-CMV phagemid vector (Stratagene) at the EcoRI restriction site. Sequence of the resulting construct was confirmed twice by DNA sequencing ( $A B I$ PRISM Dye Terminator Cycle Sequencing Ready Kit; Perkin-Elmer).

\section{Cell culture and transient transfection}

BAEC (passages 4-10) were grown on 100-mm cell culture plates using medium and instructions supplied by the manufacturer (Clonetics, San Diego, USA). Confluent COS-7 cells (American Type and Culture Collection, Manassas, VA, USA) grown in high glucose DMEM (Invitrogen, Rockville, MD, USA) supplemented with 10\% FBS and penicillinstreptomycin, $40 \mathrm{U} / \mathrm{ml}$, were transfected with plasmid DNA ( $4 \mu \mathrm{g} / 100-\mathrm{mm}$ cell culture plate) using Lipofectamine Plus in combination with Lipofectamine according to the manufacturer's protocol (Invitrogen, Rockville, MD, USA). Time-course experiments were initiated, unless otherwise noted, $48 \mathrm{~h}$ after transfection. Staurosporine (Sigma) VAD-fmk (Sigma) stock solutions in DMSO for cell culture experiments were used either fresh or stored at $-20^{\circ} \mathrm{C}$ for up to 1 month.

\section{eNOS IPs}

Cells used to prepare sample lysates for eNOS IP experiments were prepared from transiently transfected COS-7 cells, as detailed above. Cells (two 100-mm culture plates/sample) were harvested on ice by scraping and sedimented by centrifugation $\left(1000 \times g, 5 \mathrm{~min}, 4^{\circ} \mathrm{C}\right)$. Supernatants were discarded and cell pellets were sonified for $15 \mathrm{~s}$ in $1 \mathrm{ml}$ of ice-cold IP buffer I ( $50 \mathrm{mM}$ Tris-HCl, pH 7.5, $20 \mathrm{mM}$ CHAPS, $125 \mathrm{mM}$ $\mathrm{NaCl}, 2 \mathrm{mM}$ dithiothreitol, $0.1 \mathrm{mM}$ EDTA, $1 \mathrm{mM}$ orthovanadate and protease inhibitor cocktail (Complete, EDTA free, Roche, Indianapolis, IN, USA, as per the manufacturer's instructions)). After centrifugation (microcentrifuge, $6000 \times \mathrm{g}, 5 \mathrm{~min}, 4^{\circ} \mathrm{C}$ ), $1 \mathrm{ml}$ sample supernatants were incubated $\left(1 \mathrm{~h}, 4^{\circ} \mathrm{C}\right)$ with eNOS antibody (C-terminal-specific mouse antieNOS antibody, BD Transduction Laboratories, San Diego CA, USA, $5 \mu \mathrm{g} /$ $1 \mathrm{ml}$ sample) followed by incubation $\left(1 \mathrm{~h}, 4^{\circ} \mathrm{C}\right)$ with protein $\mathrm{A} / \mathrm{G}(50 \mu \mathrm{l}$ of a $50 \%$ bead slurry per sample, Pierce, Rockford, IL, USA). Samples were briefly centrifuged $(5000 \times g, 30 \mathrm{~s})$, supernatants were discarded and bound proteins were eluted from beads for quantification of immunoprecipitated eNOS protein by immunoblotting.

\section{eNOS co-IPs with CaM}

For these experiments, cells were prepared as detailed above and sonified in $1 \mathrm{ml}$ of ice-cold IP buffer II (50 mM Tris- $\mathrm{HCl}, \mathrm{pH} 7.5,20 \mathrm{mM}$ CHAPS, $125 \mathrm{mM} \mathrm{NaCl}, 2 \mathrm{mM}$ dithiothreitol, $1 \mathrm{mM}$ EGTA, $1 \mathrm{mM}$ orthovanadate and protease inhibitor cocktail (Complete, EDTA free, Roche, Indianapolis, IN, USA, as per the manufacturer's instructions)). After centrifugation (microcentrifuge, $6000 \times \mathrm{g}, 5 \mathrm{~min}, 4^{\circ} \mathrm{C}$ ), $1 \mathrm{ml}$ sample supernatants were brought to $2.5 \mathrm{mM} \mathrm{CaCl}_{2}$ (final concentration) and IP was carried out as described above with the same anti-eNOS antibody. After IP, samples were washed twice $\left(5 \mathrm{~min}\right.$ each, $4^{\circ} \mathrm{C}$ ) with $1 \mathrm{ml}$ of IP buffer II containing $2.5 \mathrm{mM} \mathrm{CaCl}_{2}$ and bound proteins were eluted from beads to quantify both immunoprecipitated eNOS and bound CaM by immunoblot.

\section{eNOS binding to CaM affinity resin}

For these experiments, cells were prepared as detailed above for co-IP of eNOS with CaM, with the following exceptions. Instead of adding eNOSspecific antibody to the $1 \mathrm{ml}$ lysate, CaM affinity resin (50 $\mu \mathrm{l}$ of a $50 \%$ bead slurry $/ 1 \mathrm{ml}$ sample, Stratagene) was added to the lysate and samples were incubated ( $1 \mathrm{~h}, 4^{\circ} \mathrm{C}$ with mixing). Beads were washed twice ( $5 \mathrm{~min}$ each, $4^{\circ} \mathrm{C}$ with mixing) with $1 \mathrm{ml}$ of IP buffer II containing $2.5 \mathrm{mM} \mathrm{CaCl}_{2}(1 \mathrm{ml} /$ wash), and proteins bound to beads were eluted for quantification of eNOS by immunoblotting.

\section{Proteolysis of eNOS by recombinant caspase-3, caspase- 6 and caspase-7}

IP of eNOS was carried out as described above, with the following exceptions. After incubation of samples with eNOS antibody in IP buffer I, protein $A / G$ beads were washed once $\left(2 \mathrm{~min}, 4^{\circ} \mathrm{C}\right)$ with $1 \mathrm{ml}$ of caspase assay buffer (50 mM HEPES, pH 7.4, $100 \mathrm{mM} \mathrm{NaCl}, 0.1 \%$ (w/v) CHAPS, $1 \mathrm{mM}$ EDTA, $10 \%$ (v/v) glycerol, $10 \mathrm{mM}$ dithiothreitol); after centrifugation $(5000 \times g, 30 \mathrm{~s})$, supernatants were discarded and beads were incubated $\left(30^{\circ} \mathrm{C}, 1 \mathrm{~h}\right)$ in caspase assay buffer without or with $50 \mu \mathrm{M}$ zVAD-fmk or vehicle (DMSO, $0.1 \%$ final concentration) in a total volume of $40 \mu$ l without or with $800 \mathrm{U}$ of recombinant caspase-3 $\left(1 \mathrm{U}=1 \mathrm{pmol} / \mathrm{min}\right.$ at $30^{\circ} \mathrm{C}$ with $200 \mu \mathrm{M}$ acetyl-Asp-Glu-Val-Asp-p-nitroanilide as substrate, as specified by the manufacturer (BioMol, Plymoth, MA, USA), recombinant caspase- 6 $\left(1 \mathrm{U}=1 \mathrm{pmol} / \mathrm{min}\right.$ at $30^{\circ} \mathrm{C}$ with $200 \mu \mathrm{M}$ acetyl-Val-Glu-lle-Asp-p-nitroanilide as substrate, as specified by the manufacturer (BioMol, Plymoth, MA, USA) or recombinant caspase-7 $\left(1 \mathrm{U}=1 \mathrm{pmol} / \mathrm{min}\right.$ at $30^{\circ} \mathrm{C}$ with $200 \mu \mathrm{M}$ acetyl-Asp-Glu-Val-Asp-p-nitroanilide as substrate, as specified by the manufacturer (BioMol, Plymoth, MA, USA). Reactions were terminated by 
the addition of $20 \mu$ of LDS-PAGE sample buffer and heated (10 min, $70^{\circ} \mathrm{C}$ ), and immunoprecipitated eNOS protein was quantified by immunoblotting.

\section{eNOS enzymatic assays}

eNOS activity was assayed either in cell lysates (typically $30 \mu \mathrm{g}$ of cell lysate per sample) or with immunoprecipitated eNOS bound to protein A/G beads. For assay of lysates, cell pellets were washed in $10 \mathrm{ml}$ of ice-cold phosphate-buffered saline and, after centrifugation $(1000 \times \mathrm{g}, 3 \mathrm{~min}$, $4{ }^{\circ} \mathrm{C}$ ), supernatants were discarded. Cells were lysed by sonification of cell pellets in ice-cold buffer containing $25 \mathrm{mM}$ Tris- $\mathrm{HCl}$, pH 7.4, $1 \mathrm{mM}$ EDTA, $1 \mathrm{mM}$ EGTA, $1 \mathrm{mM}$ dithiothreitol, $1 \mathrm{mM} \mathrm{BH}$, $1 \mathrm{mM}$ leupeptin, $0.2 \mathrm{mM}$ phenylmethylsulfonyl fluoride ( $500 \mu \mathrm{l} /$ cell pellet); lysate protein concentrations were measured using Bio-Rad protein assay with bovine serum albumin as the standard. Assays (in triplicate) were initiated by the addition of lysate (30 $\mu \mathrm{g}$ of protein) to $200 \mu$ substrate mixture $(50 \mathrm{mM}$ Tris/ $\mathrm{HCl}, \mathrm{pH}$ 7.5, $1 \mathrm{mM}$ dithiothreitol, $10 \mu \mathrm{M} \mathrm{BH} 4,4 \mu \mathrm{M}$ FMN, $4 \mu \mathrm{M} \mathrm{FAD,} \mathrm{CaM}(10 \mu \mathrm{g} / \mathrm{ml})$, $2.5 \mathrm{mM} \mathrm{CaCl} 2,1 \mathrm{mM}$ NADPH, $20 \mu \mathrm{M}$ L-arginine (with L-[2,3,4,5- $\left.{ }^{3} \mathrm{H}\right]$ arginine hydrochloride, $0.5 \mu \mathrm{Ci}$ per assay, Amersham). After incubation for $10 \mathrm{~min}$ at $37^{\circ} \mathrm{C}$, reactions were terminated by the addition of $500 \mu \mathrm{l}$ sample of ice-cold $50 \mathrm{mM}$ HEPES, pH 5.5, containing $5 \mathrm{mM}$ EDTA, and a sample $(300 \mu \mathrm{l})$ of each reaction mixture was applied to a 1-ml column of Dowex AG 50W-X8 ( $\mathrm{Na}^{+}$form) that had been pre-equilibrated to $\mathrm{pH}$ 5-6 with double-deionized water after rinsing the resin received from the supplier (Bio-Rad) three times with $1 \mathrm{M} \mathrm{NaOH}$. Radiolabelled citrulline was eluted with four 1 -ml volumes of double-deionized water and quantified by liquid scintillation counting.

For assay of immunoprecipitated eNOS, lysates were prepared as described above except that cell pellets were sonified in $1 \mathrm{ml}$ of ice-cold IP buffer III (25 mM Tris-HCl, pH 7.5; $1 \mathrm{mM}$ EGTA, $1 \mathrm{mM}$ EDTA, $1 \mathrm{mM}$ dithiothreitol, $10 \mu \mathrm{M} \mathrm{BH} 4,4 \mu \mathrm{M}$ FMN, $4 \mu \mathrm{M}$ FAD, CaM $(10 \mu \mathrm{g} / \mathrm{ml}), 2.5 \mathrm{mM}$ $\mathrm{CaCl}_{2}, 1 \mathrm{mM}$ leupeptin, $0.2 \mathrm{mM}$ pepstatin, $20 \mathrm{mM}$ CHAPS, $10 \%$ glycerol). After centrifugation (microcentrifuge, $14000 \times g, 5 \mathrm{~min}, 4^{\circ} \mathrm{C}$ ), samples of supernatants were assayed for protein (Bio-Rad protein assay) and lysate protein concentrations were equalized (usually $1-2 \mathrm{mg} / 1 \mathrm{ml}$ sample) by addition of ice-cold IP buffer III. The mouse anti-eNOS antibody $(10 \mu \mathrm{l} / 1 \mathrm{ml}$ sample) was added and after $1 \mathrm{~h}$ at $4^{\circ} \mathrm{C}, 50 \mu \mathrm{l}$ of protein $\mathrm{A} / \mathrm{G}(50 \%$ slurry; Pierce, Rockford, IL, USA) were added followed by incubation (30 min, $4^{\circ} \mathrm{C}$ with mixing), before centrifugation $(5000 \times g, 30 \mathrm{~s})$. Supernatants were discarded and beads were incubated $\left(20 \mathrm{~min}, 37^{\circ} \mathrm{C}\right)$ in $600 \mu \mathrm{l} \mathrm{eNOS}$ substrate mixture $(50 \mathrm{mM}$ Tris/ $\mathrm{HCl}, \mathrm{pH} 7.5,1 \mathrm{mM}$ dithiothreitol, $10 \mu \mathrm{M}$ $\mathrm{BH}_{4}, 4 \mu \mathrm{M}$ FMN, $4 \mu \mathrm{M}$ FAD, CaM $(10 \mu \mathrm{g} / \mathrm{ml}), 2.5 \mathrm{mM} \mathrm{CaCl} 2,1 \mathrm{mM}$ $\mathrm{NADPH}, 20 \mu \mathrm{M}$ L-arginine (with $\mathrm{L}-\left[2,3,4,5-{ }^{3} \mathrm{H}\right]$ arginine hydrochloride, $0.5 \mu \mathrm{Ci}$ per assay). Reactions were terminated by transfer of $550 \mu \mathrm{l}$ of each assay medium supernatant into $800 \mu$ l of ice-cold $50 \mathrm{mM} \mathrm{HEPES}, \mathrm{pH}$ 5.5 , containing $5 \mathrm{mM}$ EDTA on ice, followed by transfer of one-half of each $1.35 \mathrm{ml}$ reaction mixture to a $1-\mathrm{ml}$ column of Dowex AG $50 \mathrm{~W}-\mathrm{X} 8\left(\mathrm{Na}^{+}\right.$ form) for separation and radioassay of ${ }^{3} \mathrm{H}$-labeled citrulline as described above. Immediately after eNOS assay, beads were rinsed twice with $0.5 \mathrm{ml}$ of $50 \mathrm{mM}$ Tris- $\mathrm{HCl}, \mathrm{pH} 7.5$, to remove radioactive arginine, and $30 \mu \mathrm{l}$ of LDS-PAGE sample buffer were added. After heating $\left(70^{\circ} \mathrm{C}\right.$, $10 \mathrm{~min}$ ), and separation of proteins by LDS-PAGE, eNOS protein for each respective eNOS assay was quantified by immunoblotting.

\section{Immunoblots}

Proteins in samples of whole-cell lysate or immunoprecipitated eNOS were separated by LDS-PAGE in NuPAGE $4-12 \%$ Bis-Tris gels (Invitrogen), according to the manufacturer's protocol and transferred to nitrocellulose membranes. Membranes were incubated with blocking buffer $(50 \mathrm{mM}$ Tris- $\mathrm{HCl}$, pH 7.5; $150 \mathrm{mM} \mathrm{NaCl}, 5 \%$ non-fat dry milk, $0.2 \%$ Tween-20) followed by primary antibody (either C-terminal-specific rabbit anti-eNOS antibody (Santa Cruz Biotechnology, Santa Cruz, CA, USA; 1:5000 dilution), eNOS serine-1177 antibody (Cell Signaling, Beverly, MA, USA; 1:1000 dilution), eNOS threonine-495 antibody (Cell Signaling, Beverly, MA, USA; 1:1000 dilution), PARP antibody (BioMol, Plymoth Meeting, PA, USA; 1:5000 dilution) or CaM antibody (Zymed Laboratories, San Francisco, CA, USA; 1:2000 dilution) and then horseradish peroxidase-conjugated secondary antibody, either anti-rabbit or antimouse IgG (Promega, Madison, WI, USA; 1: 10000 dilution). All steps were at room temperature with incubation times of $1 \mathrm{~h}$. Immunoreactive proteins were detected by chemiluminescence (ECL, Amersham Pharmacia or SuperSignal West Dura Extended Duration Substrate, Pierce) and quantified by densitometry (Personal Densitometer SI, Molecular Dynamics).

\section{Caspase-3 enzymatic assays}

Caspase- 3 activity was quantified by colorimetric assay at $405 \mathrm{~nm}$, which measures hydrolysis of caspase-3-specific substrate (acetyl-Asp-Glu-ValAsp-p-nitroanilide) by active caspase-3, according to the manufacturer's instructions (Sigma), using cell pellets collected from one 100-mm culture dish in duplicate per assay point.

\section{Acknowledgements}

We thank Dr Martha Vaughan and Dr Vincent Manganiello for useful discussions and critical review of the manuscript.

\section{References}

1. Hengartner MO (2000) The biochemistry of apoptosis. Nature 407: 770-776

2. Meier P, Finch A and Evan G (2000) Apoptosis in development. Nature 407: 796-801

3. Ameisen JC (2002) On the origin, evolution and nature of programmed cell death: a timeline of four billion years. Cell Death Diffr. 9: 367-393

4. Nicholson DW and Thornberry NA (2003) Apoptosis: life and death decisions. Science 299: 214-215

5. Shi Y (2002) Mechanisms of caspase activation and inhibition during apoptosis. Mol. Cell 9: 459-470

6. Nicholson DW and Thornberry NA (1997) Caspases: killer proteases. Trends in Biol. Sci. 22: 299-306

7. Cohen GM (1997) Caspases: the executioners of apoptosis. Biochem. J. 326: $1-16$

8. Dragovich T, Rudin CM and Thompson CB (1998) Signal transduction pathways that regulate cell survival and cell death. Oncogene 17: 3207-3213

9. Lopez E and Ferrer I (2000) Staurosporine- and H-7-induced cell death in SHSY5Y neurosblastoma cells is associated with caspase-2 and caspase-3 activation. Mol. Brain Res. 85: 61-67

10. Feng $G$ and Kaplowitz N (2002) Mechanisms of staurosporine-induced apoptosis in murine hepatocytes. Am. J. Physiol. Gastrointest. Liver Physiol. 282: G825-G834

11. Thornberry NA and Lazebnik Y (1998) Caspases: enemies within. Science 281: 1312-1316

12. Marsden PA, Heng HH, Scherer SW, Stewart RJ, Hall AV, Shi X M, Tsui LC and Schappert KT (1993) Structure and chromosomal localization of the human constitutive endothelial nitric oxide synthase gene. J. Biol. Chem. 268: 1747817488

13. Moncada S, Higgs A and Furchgott R (1997) International Union of Pharmacology Nomenclature in Nitric Oxide Research. Pharmacol. Rev. 49: 137-142 
14. Michel T and Feron $O$ (1997) Nitric oxide synthases: which, where, how, and why? J. Clin. Invest. 100: 2146-2152

15. Raman CS, Li H, Martasek P, Krai V, Masters BS and Poulos TL (1998) Crystal structure of constitutive endothelial nitric oxide synthase: a paradigm for pterin function involving a novel metal center. Cell 95: 939-950

16. Fleming I and Busse $\mathrm{R}$ (2003) Molecular mechanisms involved in the regulation of the endothelial nitric oxide synthase. Am. J. Physiol. Regul. Integr. Comp. Physiol. 284: R1-R12

17. Wu KK (2002) Regulation of endothelial nitric oxide synthase activity and gene expression. Ann. NY Acad Sci. 962: 122-130

18. Kim PK, Zamora R, Petrosko P and BilliarTR (2001) The regulatory role of nitric oxide in apoptosis. Int. Immunopharmacol. 1: 1421-1441

19. Kim PK, Kwon YG, Chung HT and Kim YM (2002) Regulation of caspases by nitric oxide. Ann. NY Acad. Sci. 962: 42-52

20. Li J, Billiar TR, Talanian RV and Kim YM (1997) Nitric oxide reversibly inhibits seven members of the caspase family via $S$-nitrosylation. Biochem. Biophys. Res. Commun. 240: 419-424

21. Garcia-Calvo M, Peterson EP, Leiting B, Ruel R, Nicholson DW and Thornberry NA (1998) Inhibition of human caspases by peptide-based and macromolecular inhibitors. J. Biol. Chem. 273: 32608-32613

22. Dimmeler S, Haendeler J, Nehls M and Zeiher AM (1997) Suppression of apoptosis by nitric oxide via inhibition of interleukin-1-converting enzyme (ICE)- like and cytsteine protease (CPP)-32-like proteases. J. Exp. Med. 185: 601-607

23. Rossig L, Fichtlscherer B, Breitschopf K, Haendeler J, Zeiher AM, Mulsch A and Dimmeler S (1999) Nitric oxide inhibits caspase-3 by S-nitrosylation in vivo. J. Biol. Chem. 274: 6823-6826

24. Melino G, Bernassola F, Knight RA, Corasanti MT, Nistico G and Finnazzi-Agro A (1997) S-nitrosylation regulates apoptosis. Nature 388: 432-433

25. Tricot O, Mallat Z, Heymes C, Belmin J, Leseche G and Tedgui A (2000) Relation between endothelial cell apoptosis and blood flow direction in human atherosclerotic plaques. Circulation 101: 2450-2453

26. Hoffman J, Haendeler J, Aicher A, Rossig L, Vasa M, Zeiher AM and Dimmeler $S$ (2001) Aging enhances the sensitivity of endothelial cells toward apoptotic stimuli. Circ. Res. 89: 709-715

27. Harrison DG (1997) Cellular and molecular mechanisms of endothelial cell dysfunction. J. Clin. Invest. 100: 2153-2157

28. Barton M, Haudenschild CC, D'Uscio LV, Shaw S, Munter K and Luscher TF (1998) Endothilin $\mathrm{ET}_{\mathrm{A}}$ receptor blockade restores NO-mediated endothelial function and inhibits atherosclerosis in apolipoprotein deficient mice. Proc. Natl. Acad. Sci. USA 95: 14367-14372

29. Lee CM, Robinson LJ and Michel T (1995) Oligomerization of endothelial nitric oxide synthase. Evidence for a dominant negative effect of truncation mutants. J. Biol. Chem. 270: 27403-27406 